\title{
Influence of plant growth regulators and nutrients on biometric, growth and yield attributes in Blackgram (Vigna mungoL.)
}

\section{AS Sachin, T Sivakumar, K KrishnaSurendar \& M Senthivelu}

Journal of Agriculture and Ecology

ISSN: 2456-9410

Volume: 7

Journal of Agriculture and Ecology (2019) 7: 55-63 http://doi.org/10.53911/JAE.2019.7106

Volume-7 (June, 2019) ISSN: 2456-9410

\section{Journal of Agriculture and Ecology}

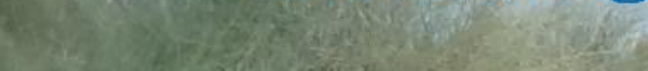

\begin{abstract}
36
\end{abstract}




\title{
Influence of plant growth regulators and nutrients on biometric, growth and yield attributes in Blackgram (Vigna mungoL.)
}

\author{
AS Sachin $\nwarrow^{1}$, T Sivakumar ${ }^{1}, \mathrm{~K}$ KrishnaSurendar ${ }^{2} \&$ M Senthivelu ${ }^{3}$ \\ ${ }^{1}$ Department of Crop Physiology, TNAU, Coimbatore, 641003. \\ ${ }^{2}$ Department of Rice, TNAU, Coimbatore - 641003. \\ ${ }^{3}$ Water Technology Centre, TNAU, Coimbatore, 641003, India. \\ Corresponding author: AS Sachin, Email: sachinsatheendran93@gmail.com
}

\section{Article Info}

Article history

Received: 03 September

2018

Accepted: 10 September

2018

Available online: 15 June

2019

Key Words: Blackgram, Plant growth regulators, TNAU Pulse Wonder, transport efficiency.

\section{Abstract}

A study was carried on the transport efficiency of blackgram as influenced by the foliar application of plant growth regulators and nutrient mixture during rabi, 2017-18 as pot culture experiment at glass house of the Department of Crop Physiology. Foliar application of salicylic acid (SA) (250 ppm), mepiquat chloride (MC) (250 ppm), chlorocholine chloride (CCC) (150 ppm) were applied at flower initiation stage and 15 days after the first spray, on blackgram with and without the seed treatment of salicylic acid (50 ppm). TNAU Pulse Wonder (1\%) was applied as foliar spray at peak flowering stage. Among the treatments, TNAU Pulse Wonder recorded higher plant height, leaf area, leaf area index and seed yield plant ${ }^{-1}$. It is concluded that TNAU Pulse Wonder improved the source-sink relationship compared to other treatments with enhanced biometric, growth parameters and yield of blackgram.

Copyright (02019 Sachin et al., This is an open access article published under the terms of the Creative Commons Attribution License, which permits unrestricted use, distribution, and reproduction in any medium, provided the original work is properly cited.

Preferred citation: Sachin AS, Sivakumar T, KrishnaSurendar K \& Senthivelu M. 2019. Influence of plant growth regulators and nutrients on biometric, growth and yield attributes in Blackgram (Vigna mungoL.). Journal of Agriculture and Ecology, 7: 55-63; http://doi.org/10.53911/JAE.2019.7106.

\section{Introduction}

Agriculture still remains the backbone of Indian economy in spite of various technological advancements and industrial development with $70 \%$ of people dependent on agriculture and $25 \%$ of country's Gross Domestic Product (GDP) coming from agricultural sector. In Indian agriculture, pulses play an important role and India is a major pulse growing country. The pulses fit well in crop rotation and crop mixture thus forming an integral part of cropping system of Indian farmers. Pulses are the cheapest source of quality protein and they provide the protein component for a balanced diet of the people (Sritharan et al., 2015). The per capita consumption of pulses in our country is just 40 $\mathrm{g}$ which is lower than the recommendation of the Indian Council of Medical Research (ICMR) and World Health Organization (WHO) which is $45 \mathrm{~g}$ and $80 \mathrm{~g}$ respectively. Thus, the requirement of pulses asper the 
recommendations of ICMR and WHO for billion people would be 17.15 million tonnes and 29.2 million tonnes respectively (Jagannathan et al. 2000).

\section{Blackgram [Vignamungo(L.) Hepper]} occupies an important place among the premier pulse crops in India. Blackgram is an extensively grown grain legume and belongs to Fabaceae family and got noticeable significance from the point of food and nutritional security in the world (Thakur et al. 2017). Blackgram is a perfect combination of all nutrients which include 20 to $25 \%$ proteins, 40 to $47 \%$ starch, ash fats, carbohydrates and essential vitamins (Manjri et al., 2018). Regarding the states, Uttar Pradesh and Maharashtra occupy the first two positions, contributing over $32 \%$. Individually, Madhya Pradesh and Andhra Pradesh contribute $14 \%$ each to the total production (GoI, 2014-15). In Tamil Nadu, blackgram is cultivated in $0.365 \mathrm{~m}$ ha with a production of 0.31 million tonnes with an average productivity of $851 \mathrm{~kg} \mathrm{ha}^{-1}$ (TNstat, 2014). Plant growth regulators are chemicals which provide optimum vegetative growth and increased source partitioning in the reproductive organs so that the yield is sufficiently increased by regulating plant growth and architecture. Ever since their invention, plant growth regulators have emerged as "magic chemicals" that could increase agricultural yield at an appealing rate. Plant growth regulators when added to the plant in a very minute concentration at critical growth periods stimulate the regulatory mechanism from seed germination to senescence in a variety of crop plants. The increased source-sink relationship using growth regulators include enhanced transport of assimilates from source and thereby increases productivity (Shinde, Univ. Agril. Sci, Dharwad,Unpublished data 2010).

\section{Material and Methods}

The pot culture experiment was conducted in the Glass house of the Department of Crop Physiology, Tamil Nadu Agricultural University, Coimbatore during rabi, 2017-18 with blackgram variety CO 6 . The location is in Western Agro-Climatic Zone of Tamil Nadu at $11.01^{\circ} \mathrm{N}$ latitude and $76.39^{\circ} \mathrm{E}$ longitude and at an altitude of 426.7 $\mathrm{m}$ above MSL.Red sandy soil was used for pot culture experiment at glass house. Soil mixture was prepared by using red soil, sand and farmyard manure (FYM) in the ratio of 2:1:1. Medium size pots were filled with 12 $\mathrm{kg}$ of soil. The experimental design was completely randomized design with 10 treatments and 3 replications. Crop received recommended dose of fertilizers $(25 \mathrm{~kg} \mathrm{~N}+$ $50 \mathrm{~kg} \mathrm{P}_{2} \mathrm{O}_{5}+25 \mathrm{~kg} \mathrm{~K}_{2} \mathrm{O} \mathrm{ha}^{-1}$ ). The treatment included foliar spray of salicylic acid (250 ppm), mepiquat chloride (250 ppm), Chlorocholine chloride (150 ppm) and TNAU Pulse Wonder (1\%) and control. The treatments were similarly given to seed treated (salicylic acid, $50 \mathrm{ppm}$ ) and nontreated blackgram plants. SA, MC, CCC were applied at flower initiation and 15 days after first spray. Plant height was measured from the ground level to the tip of the growing point and expressed as $\mathrm{cm}$. Leaf area plant ${ }^{-1}$ was measured using leaf area meter (LICOR, Model LI 3000) and expressed as $\mathrm{cm}^{2}$ plant $^{-1}$. The leaf area existing on unit ground area 
was proposed by Watson (1952) as on appropriate measure of crop growth .This measure is known as leaf area index. It is a dimensionless ratio and calculated by following formula.

$$
\mathrm{LAI}=\frac{\text { Leaf area }}{\text { Ground Area }}
$$

Specific leaf weight was calculated by using the formula of Pearce et al. (1968) and expressed in $\mathrm{mg} \mathrm{cm}^{-2}$.

$$
\text { SLW }=\begin{gathered}
\text { Leaf dry weight per plant } \\
\text { Leaf area per plant }
\end{gathered}
$$

The plants harvested from each treatment were threshed and the seed yield was recorded and expressed in grams plant $^{-1}$ from the dried whole plant sample.

\section{Results and Discussion}

\section{Plant height}

It is an important parameter that determines the growth and development of a plant. Generally, the plants with vigorous growth usually produce taller plants until maturity and are expected to give higher yield. In the present study, seed treatment with salicylic acid $50 \mathrm{ppm}$ and foliar application of nutrients significantly influenced plant height of blackgram over control. The maximum mean height (40.46 $\mathrm{cm})$ during pre-flowering phase was recorded in the seed treated (SA, $50 \mathrm{ppm})$ plants compared to the average height $(36.93 \mathrm{~cm})$ of the non-seed treated plants. This result was in close confirmity with the findings of Brunes et al. (2014) in soybean and also similar results were reported by Jadhav \& Bhamburdekar (2011) in groundnut cultivars. The plant height increased during post treatment stage and the highest was registered in TNAU Pulse Wonder spray $(53.03 \mathrm{~cm})$ along with the seed treatment followed by salicylic acid $(52.53 \mathrm{~cm})$ with seed treatment and TNAU Pulse Wonder $(52.07 \mathrm{~cm})$ without seed treatment. Significant increase in plant height upon foliar application can be attributed to the fact that micronutrients enhance plant vigour and strengthen the stalk as reported by Das(1999). The application of growth retardants like CCC (1.49\%) and mepiquat chloride $(0.68 \%)$ decreased the plant height compared to control as shown in Figure 1. The decrease in plant height may be attributed to the hindrance in gibberellic acid biosynthesis by the plant growth retardants and these observations were in close agreement with Dhaka and Anamika (2003) who reported similar results in broad bean while Jeya kumar and Thangaraj (1996)) observed similar findings in groundnut. 


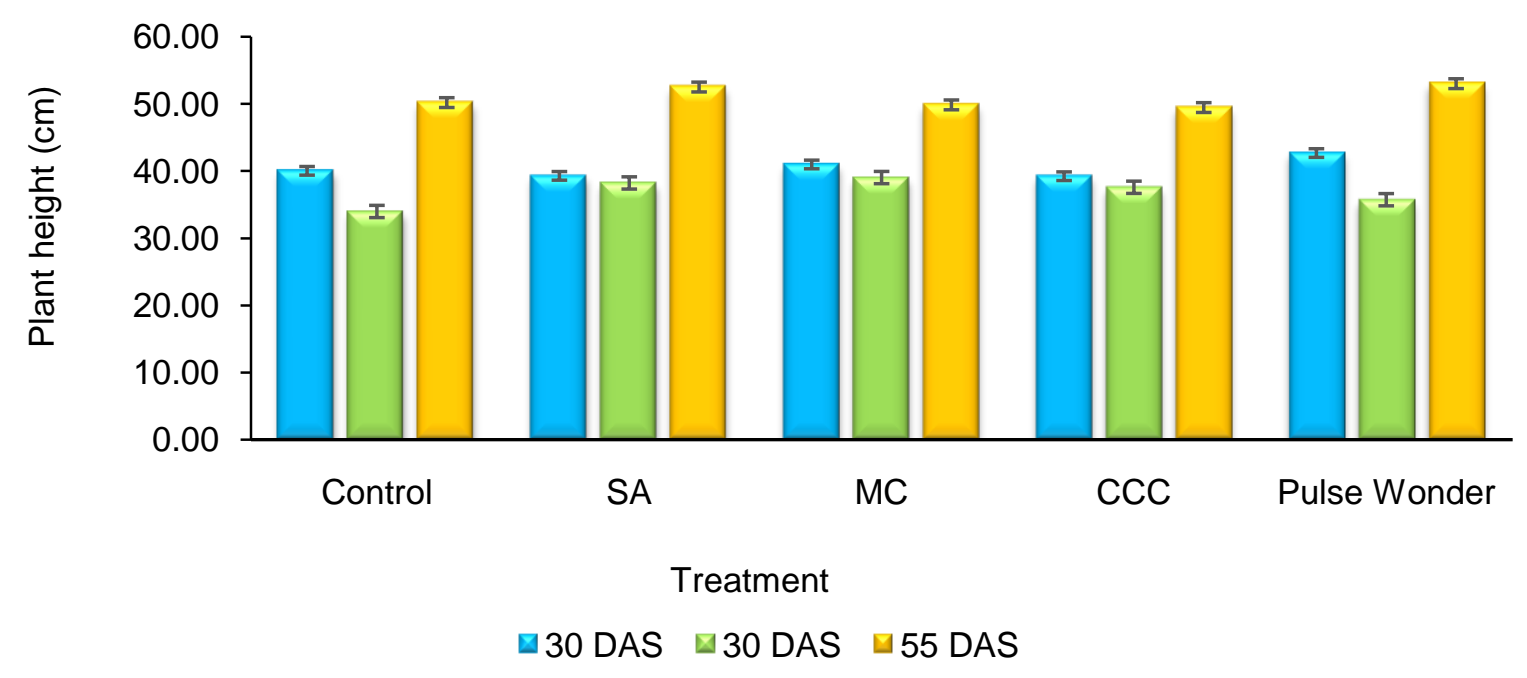

Figure 1. Effect of plant growth regulators and nutrients on plant height $(\mathrm{cm})$

\section{Leaf area}

The leaf area is an important component that is closely related to physiological processes controlling the dry matter production and yield. The index of photosynthesizing surface is represented by leaf area. The result of the present study indicates the influence of PGRs and nutrients on leaf area improvement. Seed treatment with $50 \mathrm{ppm}$ SA exhibited a profound effect on leaf enlargement. These findings were confirmed by the result of Kaydan et al. (2007) in wheat. This can be attributed to the increased seed vigour, disease resistance and growth imparted by salicylic acid.The leaf area exhibited an increasing trend from 30 to 55 days after sowing due to the application of plant growth regulators. TNAU Pulse Wonder as foliar spray and seed treatment registered highest leaf area $\left(1648.76 \mathrm{~cm}^{2}\right)$ over control which was followed by Chlorocholine chloride $\left(1154.92 \mathrm{~cm}^{2}\right)$ with seed treatment and TNAU Pulse wonder without seed treatment $\left(1063.58 \mathrm{~cm}^{2}\right)$. Application of mepiquat chloride and salicylic acid also exhibited an increase in leaf area over control. These results were supported by the observations of Amutha et al. (2012) and Marimuthu and Surendran (2015) in blackgram (Table 1). The increased leaf area by pulse wonder can be attributed to the fact that nitrogen and other micro nutrients arrested chlorophyll degradation and promoted the synthesis of photosynthetic enzymes and maintained higher auxin level which might have resulted in better plant height, leaf area, higher chlorophyll content and more assimilatory surface area for longer time. The growth retardants reduce the plant height and increases branching thereby increasing the photosynthetic leaf area. This was in justification with the findings of Prakash et al. (2003) in blackgram and Chandrababu et al. (1995) in groundnut. 
Table 1. Effect of PGRs and nutrients on leaf area $\left(\mathrm{cm}^{2}\right.$ plant $\left.^{-1}\right)$

\begin{tabular}{lllllll}
\hline \multirow{2}{*}{ Treatments } & \multicolumn{3}{c}{ Pre-flowering (30 DAS) } & \multicolumn{3}{c}{ Post-flowering (55 DAS) } \\
\cline { 2 - 7 } & $\mathrm{C}_{1}$ & $\mathrm{C}_{2}$ & Mean & $\mathrm{C}_{1}$ & $\mathrm{C}_{2}$ & Mean \\
\hline $\mathrm{T}_{1-}$ Control & 299.92 & 231.81 & 265.87 & 643.16 & 636.56 & 639.86 \\
$\mathrm{~T}_{2-}$ Salicylic acid (250 ppm) & 298.87 & 278.03 & 288.45 & 794.07 & 715.07 & 754.57 \\
$\mathrm{~T}_{3-}$ Mepiquat chloride (250ppm) & 323.29 & 261.65 & 292.47 & 903.00 & 845.24 & 874.12 \\
$\mathrm{~T}_{4-\text { Chlorocholine chloride (150 }}$ & 311.18 & 267.83 & 289.51 & 1154.92 & 894.23 & 1024.58 \\
ppm) & & & & & & \\
$\mathrm{T}_{5-\text { TNAU Pulse Wonder (1\%) }}$ & 321.52 & 261.55 & 291.54 & 1648.76 & 1063.58 & 1356.17 \\
\hline Mean & 310.96 & 260.17 & & 1028.78 & 830.94 & \\
SEd & & 6.57 & & & 22.45 & \\
\multicolumn{1}{c}{ CD (P=0.05) } & & 13.71 & & & 46.83 & \\
\hline
\end{tabular}

$\mathrm{C}_{1}$ : Seed treatment with $50 \mathrm{ppm}$ Salicylic acid, $\mathrm{C}_{2}$ : Without seed treatment ; DAS: Days after sowing

\section{Leaf area index}

LAI is one of the standard factors prompting canopy net photosynthesis of the crop plants. Leaf area index was also greatly influenced by salicylic acid seed treatment as recorded in the present study. During preflowering stage, average leaf area index was found to be more in seed treated plants (Figure 2). During the post treatment stage, TNAU Pulse Wonder (3.36) with seed treatment showed more LAI than that of control, which was followed by CCC (2.35) with seed treatment and TNAU Pulse Wonder without seed treatment (2.17). Increased LAI can be attributed to the increased leaf area upon plant growth regulators application and these findings were in close confirmity with the results of Marimuthu and Surendran (2015) in blackgram and Chandrababu et al. (1995) in groundnut.

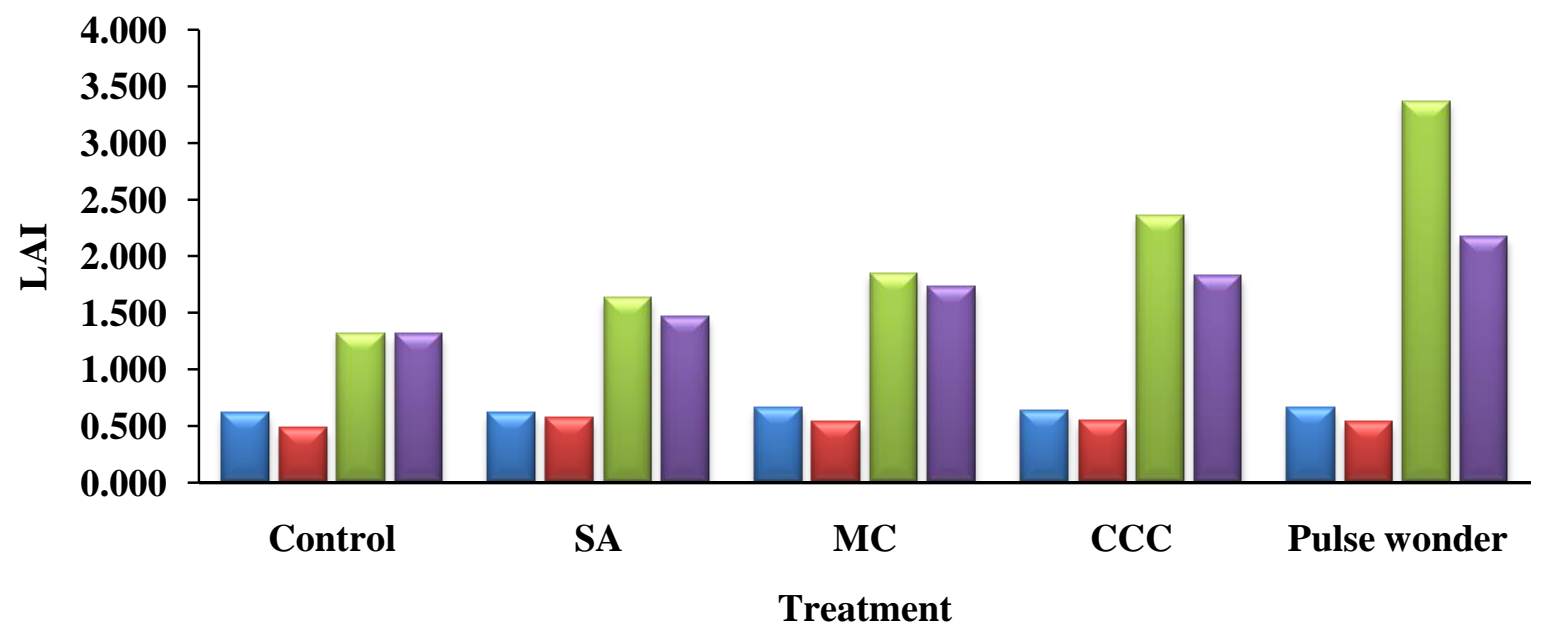

$\square 30$ DAS $\square 30$ DAS $\square 55$ DAS $\square 55$ DAS

Figure 2. Effect of plant growth regulators and nutrients on leaf area index 


\section{Specific leaf weight}

SLW is an excellent parameter to assess the translocation efficiency of crop plants. Specific leaf weight, a measure of leaf thickness, has been reported to have a strong positive correlation with leaf photosynthesis of several crops as reported by Bowes et al. 1972. This study revealed that the average SLW during vegetative phase was noticed to be more in seed treated plants. After the application of treatments TNAU Pulse Wonder with seed treatment was found to increase the SLW by $12.24 \%$ over control which was closely followed by SA with seed treatment $(10.20 \%)$ and CCC with seed treatment (10.20\%) (Figure 3). This findings were in close confirmity with Kulkarni (University of Agricultural Sciences, Unpublished results, 1993) who reported similar observations in sunflower.Dornhoff \& Shibles (1970) reported that higher SLW might be associated with higher cell surface to volume ratio which might lower mesophyll resistance to $\mathrm{CO}_{2}$ entry and increases photoassimilate accumulation in soybean. Thicker leaves would have more number of mesophyll cells with high density of chlorophyll and, therefore, have a greater photosynthetic capacity than thinner leaves (Craufurd et al. 1999; Balai et al. 2017).

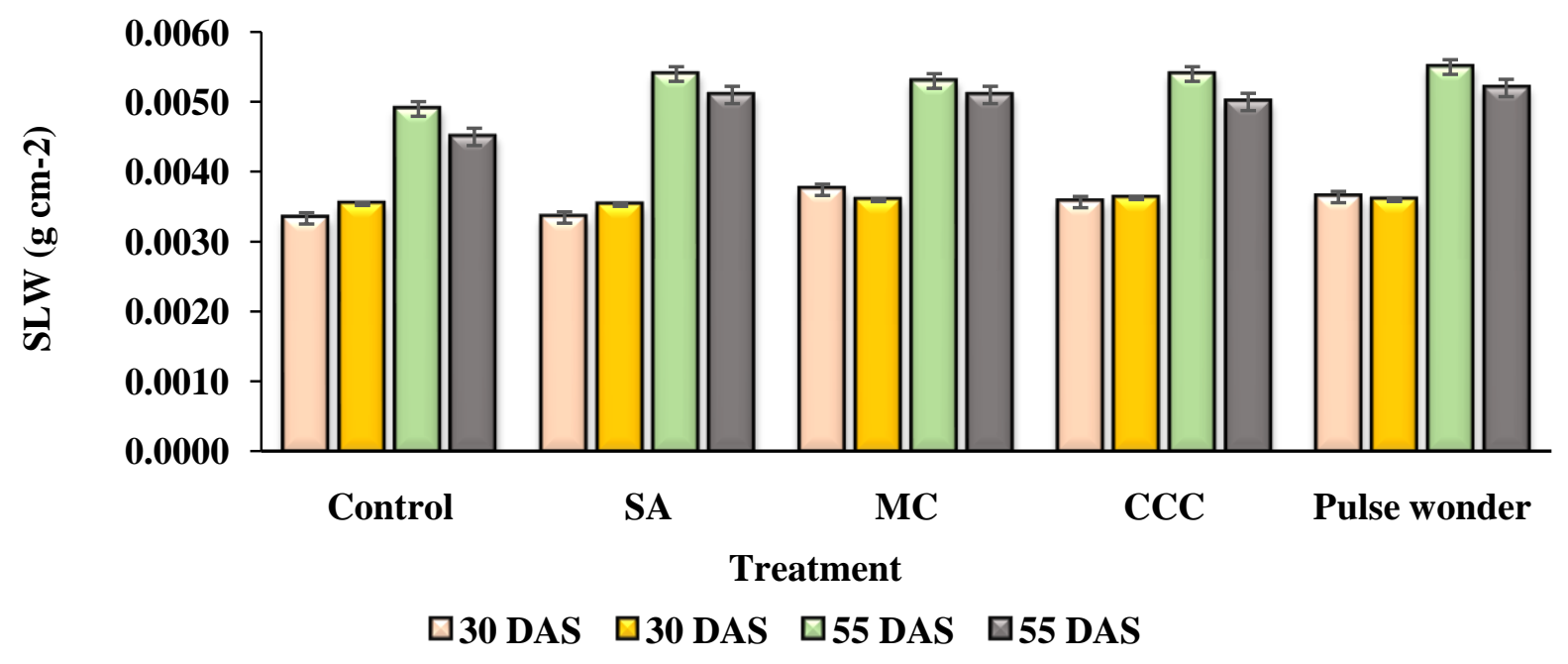

Figure 3. Effect of plant growth regulators and nutrients on specific leaf weight $\left(\mathrm{gcm}^{-2}\right)$

\section{Seed yield plant ${ }^{-1}$}

The yield was markedly increased by the application of foliar nutrients. In the current study TNAU Pulse Wonder with seed treatment increased the seed yield $(4.13 \mathrm{~g})$ over control followed by TNAU Pulse Wonder without seed treatment $(3.77 \mathrm{~g})$ whereas CCC
$(3.57 \mathrm{~g})$ and salicylic acid $(3.52 \mathrm{~g})$ with seed treatment had also increased the seed yield plant $^{-1}$ (Table 2). The increased in yield might be due to enhanced yield attributes like number of pods plant ${ }^{-1}$, number of seeds pod ${ }^{-1}$. It is due to increased uptake of nutrients by 
blackgram by effective translocation of nutrients from sink to reproductive area of crop. Supporting these findings, Shinde (Univ. Agril. Sci., Dharwad, Unpublished data,2010) reported that the application of CCC, TIBA and progib and $500 \mathrm{ppm}$ CCC resulted in increased number of pods and seeds thereby increasing the total seed yield. Similar results were obtained by Prabhakar Reddy(2002) that the foliar application of salicylic acid in greengram increased seed yield. The increased seed yield by TNAU Pulse Wonder might be attributed to the composition of this nutrient mixture and was in confirmity with Jayabel et al. (1999) who reported that foliage applied macro and micronutrients at critical stages of the crop might be effectively absorbed and transported to the developing pods, producing more number of pods with better filling in soybean.

Table 2. Impact of PGRs and nutrients on seed yield plant ${ }^{-1}(\mathrm{~g})$

\begin{tabular}{llll}
\hline \multirow{2}{*}{ Treatments } & \multicolumn{3}{c}{ Seed yield plant $^{-1}$} \\
\cline { 2 - 4 } & $\mathrm{C}_{1}$ & $\mathrm{C}_{2}$ & Mean \\
\hline $\mathrm{T}_{1-\text { Control }}$ & 2.96 & 2.89 & 2.93 \\
$\mathrm{~T}_{2-}$ Salicylic acid (250 ppm) & 3.52 & 3.45 & 3.49 \\
$\mathrm{~T}_{3}$ Mepiquat chloride (250ppm) & 3.06 & 2.99 & 3.03 \\
$\mathrm{~T}_{4-}$ Chlorocholine chloride (150 ppm) & 3.57 & 3.46 & 3.52 \\
$\mathrm{~T}_{5-}$ TNAU Pulse Wonder (1\%) & 4.13 & 3.77 & 3.95 \\
\hline \multicolumn{1}{c}{ Mean } & 3.55 & 3.31 \\
SEd & \multicolumn{3}{c}{0.06} \\
CD (P=0.05) & \multicolumn{3}{c}{0.12} \\
\hline
\end{tabular}

$\mathrm{C}_{1}$ : Seed treatment with $50 \mathrm{ppm}$ Salicylic acid

$\mathrm{C}_{2}$ : Without seed treatment

\section{Conclusion}

The different plant growth regulators and nutrients used, TNAU Pulse Wonder improved the overall transport efficiency and assimilate partitioning in black gram. It was followed by growth retardant Chlorocholine chloride. Growth promoter salicylic acid and growth retardant mepiquat chloride also had impact on source-sink relationship but the effect was less effective compared to the TNAU Pulse Wonder. TNAU Pulse Wonder improved the source-sink relationship than the other treatments and enhanced the physiological, biometric, growth parameters and yield of blackgram.

\section{Acknowledgements}

I feel exulted to place on record my deep sense of gratitude and sincere thanks to my respected chairman Dr. T. Sivakumar, Associate Professor, Department of Crop Physiology for suggesting this study, his proficient and peerless guidance, sustained interest, constant inspiration throughout the study period.I am very much privileged to express my heartfelt thanks to Dr. K. Krishna Surendar, Assistant Professor, Department of Crop Physiology and Dr. M. Senthivelu, Assistant Professor, Department of Agronomy, members of the advisory committee for their inspiring guidance and suggestions at all stages of doing research and 
writing the thesis. Also I express my vote of gratitude to Dr. R. Sivakumar, Assistant Professor, for his guidance and care. Gratitude is also expressed to PG-Co ordinatorDr. A. Senthil, Associate Professor and Dr. P. Jeyakumar (Professor and Head) for their constant support and encouragement.

\section{References}

Amutha R, Nithila S \& Sivakumar T. 2012. Management of source limitation by foliar spray of nutrients and growth regulators in Blackgram. International Journal of Plant Sciences, 7(1): 65-68.

Balai RC, Meena LR \& Sharma SC. 2017. Effect of different levels of nitrogen and phosphorus on cowpea [Vigna unguiculata (L.) Walp] under rainfed conditions of Rajasthan. Journal of Agriculture and Ecology, 3: 19-24.

Bowes GW, Orgen L, Hageman RH. 1972. Light saturated photosynthesis rate, RuBp Carboxylase activity and specific leaf weight in soybean grown under different light intensities. Crop Science, 12: 77-79.

Brunes AP, Lemes ES, Dias LW, Gehling VM \& Villela FA. 2014. Performance of soybean seeds treated with salicylic acid doses. Centro Científico Conhecer Goiânia, 10: 1467-1474.

Chandrababu R, Manian K, Nagarajan M, Ramachandran T. 1995. Effect of mepiquat chloride on growth and yield of groundnut. Madras Agricultural Journal, 82(3): 229-230.

Craufurd PC, Wheelee TR, Ellis RH, Summerfield RJ \& Williams JH. 1999. Effect of temperature and water deficit on water use efficiency, carbon isotope discrimination and specific leaf weight in peanut. Crop Science, 39: 136-142.
Das PC. 1999. Plants Nutrients. In: Manures and Fertilizers. 2nd Edition. Kalyani Publishers, New Dehli, India, 5-10.

Dhaka T \& Anamika. 2003. Effect of mepiquat chloride (DPC) and urea on growth and yield attributes of broad bean (Vicia faba L.). Plant Archives, 3(2): 291-293.

Dornhoff GM \& Shibles RM. 1970. Varital differences in net photosynthesis of soybean leaves. Crop Science, 10: 4245.

Jadhav S \& Bhamburdekar S. 2011. Effect of salicylic acid on germination performance in groundnut. International Journal of Applied Biology and Pharmaceutical Technology, 2(4): 224227.

Jagannathan R, Chinnamuthu C \& Balusamy M. 2000. CAS training on recent advances in pulse crop production technology. 13.09. 2000 to 30.10. 2000.

Jayabal A, Revathy M \& Saxena MG. 1999. Effect of foliar nutrition on nutrient uptake pattern in soybean. Andhra Agriculture Journal, 46: 243-244.

Jeyakumar P \& Thangaraj M. 1996. Effect of mepiquat chloride on certain physiological and yield characteristics of groundnut (Arachis hypogaea L.). Journal of Agronomy and Crop Science.176(3): 159-164.

Kaydan D, Yagmur M \& Okut N. 2007. Effects of salicylic acid on the growth and some physiological characters in salt stressed wheat (Triticum aestivum L.). Tarim Bilimleri Dergisi, 13(2):114-119.

Kulkarni S. 1993. Effect of Growth Retardants on the Growth, Physiology and Yield Potential in Sunflower (Helianthus annus L.) Genotypes. University of Agricultural Sciences.

Manjri Singh A, Gupta SD, Bahadur R \& Singh AK. 2018. Responses of 
Blackgram (Vigna mungo) to Foliar Applied Plant Growth Regulators. International Journal of Current Microbiology and Applied Sciences, 7: 4058-4064.

Marimuthu S, Surendran U. 2015. Effect of nutrients and plant growth regulators on growth and yield of black gram in sandy loam soils of Cauvery new delta zone, India. Cogent Food \& Agriculture, 1(1): 1010415.

Pearce R, Brown R, Blaser R. 1968. Photosynthesis of Alfalfa leaves as influenced by age and environment. Crop Science, 8(6): 677-680.

Prabhakar Reddy V. 2002. Effect of growth regulators on growth, physiology and yield in chickpea((Cicer arietinum L.). (M. Sc. (Agri.) ), University of Agricultural Sciences., Dharwad.

Prakash M, Kumar JS, Kannan K, Kumar MS \& Ganesan J. 2003. Effect of plant growth regulators on growth, physiology and yield of blackgram. Legume Research-An International Journal, 26(3): 183-187.
Shinde RV. 2010. Influence of plant growth regulators on growth physiology, yield and quality of soybean [Glycine max (L.) Merrill]. (M.Sc. (Agri.)), Univ. Agril. Sci., Dharwad.

Sritharan N, Rajavel M \& Senthilkumar R. 2015. Physiological approaches: Yield improvement in blackgram. Legume Research-An International Journal, 38(1): 91-95.

Thakur V, Teggelli RG \& Meena M. 2017. Influence of Foliar Nutrition on Growth and Yield of Pulses Grown under North Eastern Dry Zone of Karnataka: A Review. International Journal of Pure Applied Bioscience, 5(5): 787-795.

TNstat, 2014. https://tn.data.gov.in

Watson DJ. 1952. The physiological basis of variation in yield. Advances in Agronomy, 4: 101-145. 